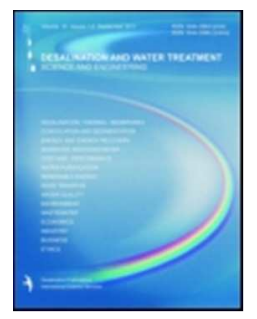

\title{
COMPARISON OF DIFFERENT WASTEWATER TREATMENTS FOR COLOUR REMOVAL OF REACTIVE DYE BATHS
}

\begin{tabular}{|r|l|}
\hline Journal: & Desalination and Water Treatment \\
\hline Manuscript ID: & TDWT-2014-2004.R1 \\
\hline Manuscript Type: & Original Paper \\
\hline Date Submitted by the Author: & n/a \\
\hline Complete List of Authors: & $\begin{array}{l}\text { Lopez-Grimau, Victor; Universitat Politecnica de Catalunya, } \\
\text { Vilaseca, Merce; Universitat Politecnica de Catalunya, INTEXTER } \\
\text { Gutierrez-Bouzan, Carmen; Universitat Politecnica de Catalunya, INTEXTER }\end{array}$ \\
\hline Keywords: & $\begin{array}{l}\text { Colour removal, Reactive dyes, Electrochemical treatment, Moringa } \\
\text { oleifera, Natural coagulant, Enzymatic treatment, Laccase }\end{array}$ \\
\hline
\end{tabular}




\section{COMPARISON OF DIFFERENT NEW WASTEWATER TREATMENTS FOR COLOUR REMOVAL OF REACTIVE DYE BATHS}

Víctor López-Grimau ${ }^{\mathrm{a}, \mathrm{b},{ }^{*},}$, Mercè Vilaseca $^{\mathrm{a}}$, Carmen Gutiérrez-Bouzán ${ }^{\mathrm{a}}$

a INTEXTER, Institute of Textile Research. Universitat Politècnica de Catalunya, 08222 Terrassa, Spain, Tel. +34 93 7398008; emails: victor.lopezgrimau@upc.edu (V. López-Grimau), vilaseca@intexter.upc.edu (M. Vilaseca), gutierrez@intexter.upc.edu (C. Gutiérrez-Bouzán).

b. Department of Projects Engineering, ETSEIAT. Universitat Politècnica de Catalunya, 08222 Terrassa, Spain, Tel. +34 937397316

* Corresponding author

\section{ABSTRACT}

The generation of high coloured wastewater is one of the main environmental problems of the textile industry. Reactive dyes are widely used in the dyeing of cellulosic fibres. However, they have low exhaustion degree (70\%-90\%). The degradation of residual dyes by aerobic conventional biological treatment is very poor, being necessary the application of specific treatments. In this work, three different methods for the removal of reactive dyes were compared: electrochemical treatment, coagulation with Moringa oleifera waste and enzymatic treatment with Laccase. Two azo bifunctional dyes with different reactive groups were selected: C.I. Reactive Black 5 (vinylsulfone) and C.I.

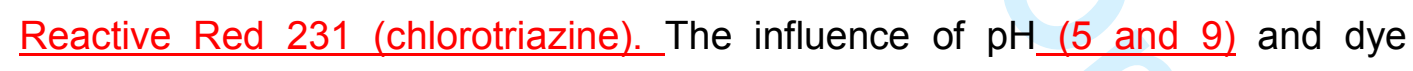
hydrolysis on the decolourisation yield was studied. The electrochemical treatment was the most efficient, with $95-100 \%$ colour removal yield. The coagulation with Moringa oleifera waste also achieved high colour removal efficiency (91-94\%). Both methods showed an independent behaviour with respect to $\mathrm{pH}$ or dye hydrolysis. The enzymatic treatment should be performed at $\mathrm{pH}$ 5. This method was suitable to remove the chlorotriazine dye $(92-93 \%$ efficiency) whereas the vinylsulfone one showed a marked dependence on dye hydrolysis: moderately efficient for the hydrolysed dye and highly efficient without hydrolysis. The activity of Laccase was not modified by the usual salinity 
32 of the reactive dyeing effluent $(20 \mathrm{~g} / \mathrm{L} \mathrm{NaCl})$. Nevertheless, This factorthe

33 effluent salinity enhanced the electrochemical and Moringa oleifera treatment 34 yield.

35 Keywords: Colour removal; Reactive dyes; Electrochemical treatment; Moringa

36 oleifera; Natural coagulant; Enzymatic treatment; Laccase.

\section{INTRODUCTION}

39

40

41

42

43

Worldwide, 280,000 tons of textile dyes are discharged in industrial effluents every year, being azo dyes the most widely used with more than $60 \%$ of the total dye production [1]. The aromatic amines generated from dyes reduction can be harmful and some of them have been classified as carcinogenic and genotoxic by the International Agency for Research on Cancer [2]. The presence of toxic and carcinogenic products in textile dyeing effluents is a problem added to the high coloration inherent to this type of effluents [3], mainly taking into account the large volume of wastewater generated by textile industry.

Among the different kind of textile dyes, reactive ones are widely used in the dyeing of cotton and other cellulosic fibres since they offer high washing fastness and brilliant colours. Reactive dyes represent the $25 \%$ of the total world market [4]. In opposite, these dyes have a low degree of exhaustion and fixation, from $70 \%$ to $90 \%$ [5]. Therefore, an important percentage of dye remains in its hydrolysed and unfixed form in the exhausted dye bath or it is removed in the washing liquors.

55 The degradation of residual dyes by aerobic conventional-biological treatment by activated sludge is very poor, since they have low biodegradability and they are also poorly adsorbed in the activated sludge [6]. As biological treatments are not able to remove colour properly, the application of specific treatments is required in order to accomplish current regulations. There are different techniques to achieve colour removal, and among them, the most used are: activated carbon adsorption [7-86-7], membrane filtration [9-108-9], coagulationflocculation processes [11-1210-11] and treatment with ozone [13-1412-13]. 
63 These technologies have been applied at industrial scale, offering a good colour 64 removal, but they have a high cost of operation and maintenance in the case of 65 membrane technologies and ozonolysis or high cost of chemical products in the 66 case of activated carbon and coagulation-flocculation reagents [5]. Different 67 research groups are working, at laboratory and pilot plant scale, on diverse new 68 methods: low cost adsorbents [15-1614-15], natural coagulants [17-1816-17], 69 enzymatic action of specific microorganisms [19-2018-19], anaerobic 70 bioreactors [2120] or advanced oxidation methods (Fenton and Photo-Fenton 71 reactions [22-2321, 22], heterogeneous photocatalysis [24-2523, 24] or 72 electrochemical oxidation $[\underline{26-2725,26]) .}$ 
95 such as ABTS (2,2'-azino-bis(3-ethylbenzothiazoline-6-sulfonic acid)) or HBT

96 (1-hydroxybenzotriazole) [32].

97 In this work, these three methods (electrochemical, Moringa oleifera waste and 98 laccase) were are applied to the removal of colour from reactive dyebaths. Two 99 azo reactive dyes were selected: C.I. Reactive Black 5 and C.I. Reactive Red 100 231. This dyes have-with different reactive groups (vinilsulfone and 101 chlorotriazine respectively) were selected in order to study their influence on the 102 treatment efficiency. The effect of $\mathrm{pH}$ and dye hydrolysis on the decolourisation 103 yield was also studied. In addition, the influence of high salt concentration was 104 evaluated, due to the high salinity characteristic of reactive dye effluents.

\section{EXPERIMENTAL}

$107 \quad 2.1$ Dye solutions

108 Two azo reactive dyes widely used in on cotton dyeing industries were selected 109 in this study: Colour Index (C.I.) Reactive Black 5 (referred as RB5) and C.I. 110 Reactive Red 231 (RR231). Both are bifunctional: RB5 has two vinylsulfonic 111 groups whereas RR231 has two monochlorotriazinic ones. The chemical 112 structure of dyes is shown in Figure 1.<smiles>COCCOCCOc1ccc(N=Nc2c([N+](=O)[O-])cc3cc([N+](=O)[O-])c(N=Nc4ccc(S(=O)(=O)OCCOC(C)=O)cc4)c(N)c3c2O)cc1</smiles>

\section{(a)}

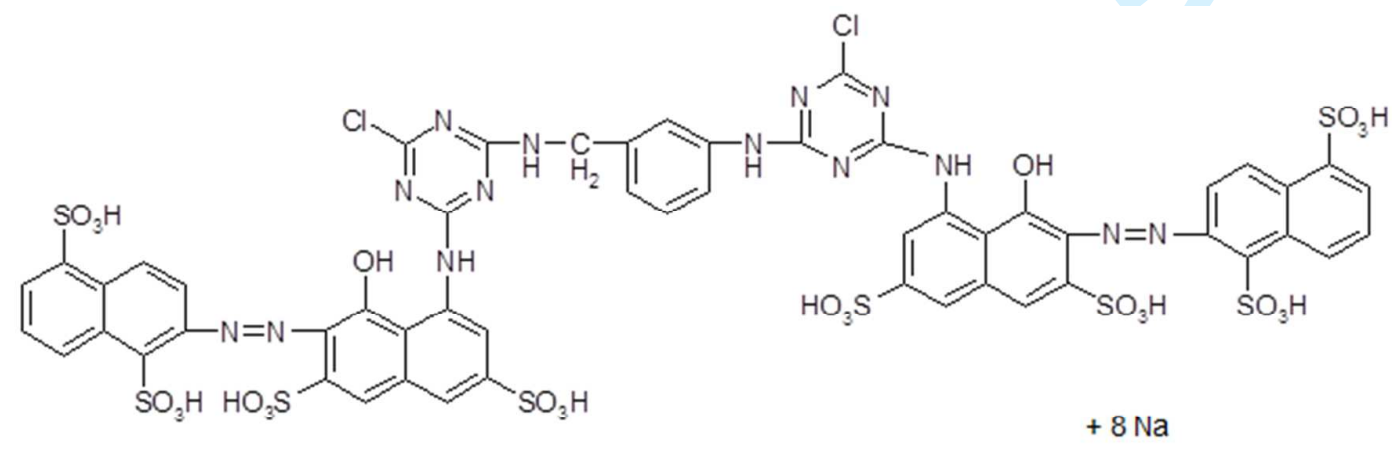


118 Figure 1. Chemical structure of the two selected dyes: (a) C.I. Reactive Black 5 119 (RB5), (b) C.I. Reactive Red 231 (RR231).

Simulated dye baths were prepared at a dye concentration of $0.1 \mathrm{~g} / \mathrm{L}$ in

122

123 decalcified water. Decolourisation tests were carried out at $\mathrm{pH} 5$ and 9, adjusted with $\mathrm{HCl} 1 \mathrm{M}$ or $\mathrm{NaOH} 1 \mathrm{M}$. To simulate a residual reactive dyeing baths, up to $20 \mathrm{~g} / \mathrm{L} \mathrm{NaCl}$ was added to all dye solutions.

The effect of dye hydrolysis on the efficiency of the three decolourisation methods was studied with the two dyes since they contain different reactive groups. The general reactions of hydrolysis for vinylsulfonic dyes (react. 1) and chlorotriazinic dyes (react. 2) are as follows:

$$
\begin{gathered}
\text { Dye- } \mathrm{SO}_{2}-\mathrm{CH}_{2}-\mathrm{CH}_{2}-\mathrm{OSO}_{3} \mathrm{Na}+{ }^{-} \mathrm{OH} \rightarrow \text { Dye- }-\mathrm{SO}_{2}-\mathrm{CH}_{2}-\mathrm{CH}_{2}-\mathrm{OH}+{ }^{-} \mathrm{OSO}_{3} \mathrm{Na}(1) \\
\text { Dye- } \mathrm{Cl}+{ }^{-} \mathrm{OH} \rightarrow \text { Dye- } \mathrm{OH}+\mathrm{Cl}^{-}
\end{gathered}
$$

The hydrolysis of chlorotriazinic dyes only implies the substitution of $\mathrm{Cl}-\mathrm{by}^{-} \mathrm{OH}^{-}$, whereas the hydrolysis of vinyl sulfonic dyes suppose the loss of a sulfonic group which can affect to the dye removal efficiency. Dye hydrolysis was carried out by boiling for $2 \mathrm{~h}$ the dye solutions at $\mathrm{pH} 12$.

\subsection{Electrochemical treatment}

Electrochemical treatments were conducted in an electrolytic cell, which was undivided. The cathodes were constituted by titanium and the anodes were made of titanium, covered by platinum oxides (Ti/PtOx anodes). The total surface area of each electrode was $486 \mathrm{~cm}^{2}$ and the distance between the electrodes was $2 \mathrm{~mm}$. The volume of the vessel was $1 \mathrm{~L}$.

The experimental plant was completed by a pump to feed the cell and a tank to store the treated wastewater. This plant operated continuously at a flow rate of $20 \mathrm{~L} / \mathrm{h}[27]$. The current was regulated by the source supply among 0 and $25 \mathrm{~A}$ (current density range: $0-50 \mathrm{~mA} / \mathrm{cm}^{2}$ ). The electrical consumption was 
146 registered during the treatment as $\mathrm{Wh} / \mathrm{L}$ taking into account the time of treatment and the volume of the sample.

\subsection{Moringa oleifera coagulation}

151

Dry Moringa oleifera seeds were supplied by the Centre National de Semences Forestières of Burkina Faso. Shells were removed manually and kernels were reduced to powder using a domestic grinder (Moulinex). $1 \mathrm{~g}$ of $\mathrm{M}$. oleifera powder fed to a Soxhlet extractor fitted with a $250 \mathrm{~mL}$ round-bottom flask and a condenser. The extraction was run for 2 hours with $100 \mathrm{~mL}$ of hexane (Sharlab). After the extraction, the solvent was distilled off under vacuum in a rotary evaporator. The oil extraction yield was $36.1 \%$. Protein content of the Moringa oleifera seeds was determined by analysis of Nitrogen Kjeldahl (protein $=\mathrm{N}(\%) \mathrm{x}$ 6.25). The protein content of seeds before extraction was $25.0 \%$ and after extraction with ethanol was $34.4 \%$. This increase in the protein content should favour the coagulant effect of Moringa oleifera solutions.

162 Oilseed residues were used to prepare a suspension at $5 \%(\mathrm{w} / \mathrm{v})$ in distilled water by stirring at room temperature for 2 hours. Later the suspension was filtered with $0.45 \mu \mathrm{m}$ glass filter (Millipore). Colour removal tests were carried out with solutions of Moringa oleifera at different concentrations of Moringseed extraction waste, ranging from 250 to $1,250 \mathrm{mg} / \mathrm{L}$. Trials with 1 liter of dye solution samples were performed in a Jar Test. The samples were first submitted to a fast stirring at $150 \mathrm{rpm}$ for 10 minutes, subsequently they were stirred slowly at $20 \mathrm{rpm}$ for 30 minutes [33] and finally they were allowed to stand 1 hour in Imhoff cones to promote natural decantation [34].

\subsection{Enzymatic treatment}

173 Laccase from the ascomycete Myceliophthora thermophila was selected for the 174 enzymatic treatments. Laccase solutions were supplied by Novozymes (Davis, 175 CA, USA). Commercial solutions were initially filtered with a cartridge Sep-Pack 176 C18 (Waters Associates, Milford, USA). Lacasse activity was determined 
177 spectrophotometrically by oxidation of ABTS (2, 2'-azino-di-[3-ethyl178 benzothiazoline-(6)-sulfonic acid]) supplied by Sigma-Aldrich (Madrid, Spain). 179 The reaction was monitored at room temperature by measuring the change in 180 absorbance at $436 \mathrm{~nm}$ for $2 \mathrm{~min}$. One activity unit was defined as the amount of 181 enzyme that oxidized $1 \mu \mathrm{mol}$ of ABTS per minute and the activities were 182 reported as $\mathrm{U} / \mathrm{mL}$. The Laccase enzyme solution showed $400 \mathrm{U} / \mathrm{mL}$ of activity.

183 The $\mathrm{pH}$ of dye solutions was fixed at 5 by addition of $0.1 \mathrm{M}$ acetate/acid acetic 184 buffer solution $\mathrm{pH} 5$, as it is a common procedure in previous literature focused 185 on the removal of Reactive Black 5 solutions [35-36]. According to our previous 186 studies no organic mediator was added to dye solutions and all the experiments 187 were performed at $50^{\circ} \mathrm{C}$ for $24-48 \mathrm{~h}$ with the addition of $4 \mathrm{U} / \mathrm{mL}$ of enzyme 188 concentration.

\subsection{Colour removal measurements}

191 Colour removal values were calculated from absorbance measurements at the 192 maximum absorbance wavelength of each dye (599 for RB5 dye and $522 \mathrm{~nm}$ 193 for RR231 dye). The absorbance measurements were carried out with a UV194 visible spectrophotometer Shimadzu UV-2401 PC model (Japan). The linearity 195 interval was previously established. All dye removal tests were carried out in 196 triplicate.

198 3. RESULTS AND DISCUSION

$199 \quad 3.1$ Electrochemical treatment

200 The results of colour removal obtained in the electrochemical treatment are 201 shown in Figure 2. Current density was initially fixed at $24 \mathrm{~mA} / \mathrm{cm}^{2}$ according to 202 previous studies [27]. As can be seen, the same experiments were performed 203 with dyes not hydrolysed and with solutions of dyes previously hydrolysed. 
Figure 2 evidences that colour removal results were almost independent on $\mathrm{pH}$.

210 Dye oxidation manly occurs through the action of oxidant species generated in the anode $(\mathrm{Cl} 2, \mathrm{Cl} \bullet, \mathrm{Cl} 2 \bullet, \mathrm{ClOH} \bullet-)$ which are independent on the $\mathrm{pH}$ [27]. The electrochemical treatment reached $98-100 \%$ of colour removal for RR231 dye and $95-96 \%$ for RB5. On the other hand, the dye hydrolysis did not have any

214 significant effect on the efficiency of the electrochemical treatment.

215 Decolourisation is mainly caused by the breakage of the chromophore (azo bond) [37]. The hydrolysis of the reactive group, located in different points of the dye molecule is not a decisive factor in this reaction and does not have effect on 

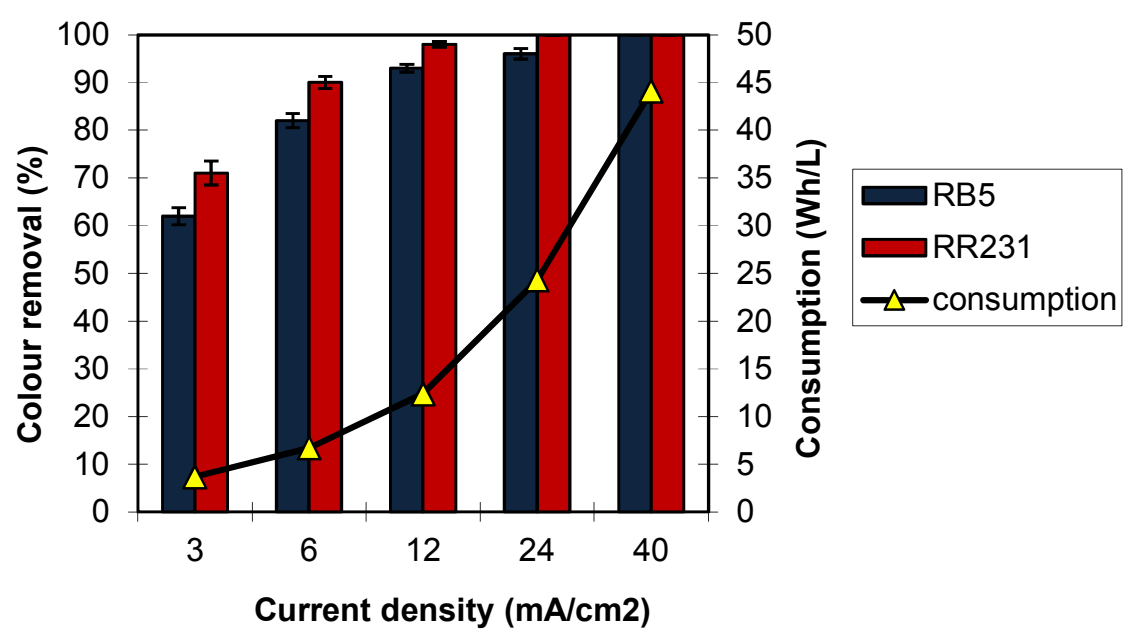

Figure 3. Optimisation of the electrochemical treatment $(0.1 \mathrm{~g} / \mathrm{L}$ hydrolysed dye, pH9, $20 \mathrm{~g} / \mathrm{L} \mathrm{NaCl}$ ).

As is shown in Figure 3, colour removal results were better for RR231 than for RB5. In this sense, almost total decolourisation was obtained for RR231 at 12 $\mathrm{mA} / \mathrm{cm}^{2}$ and $94 \%$ colour removal was reached for RB5, which electrical consumption corresponded to $12.4 \mathrm{Wh} / \mathrm{L}$. However, it can be underlined that in the case of RR231,6 mA/cm ${ }^{2}$ current density was sufficient to obtain more than $90 \%$ colour removal, which implied that the electrical consumption was drastically reduced to $6.7 \mathrm{Wh} / \mathrm{L}$. Between the two dyes, the differences in colour removal can be attributed to their different molecule structure. Both dyes have two azo chromophore groups to be degraded, so the difference between their decolourisation yield is attributed to the rest of their molecular structure [38]. RB5 degradation can produce any intermediate capable of giving slight colour to the water.

\subsection{Moringa oleifera coagulation}

Results of coagulation with Moringa oleifera suspensions are shown in Figure 4. Initially, the concentration of Moringa oleifera was fixed at $1,000 \mathrm{mg} / \mathrm{L}$, which is a common concentration of coagulant for this type of industrial wastewater [39]. 


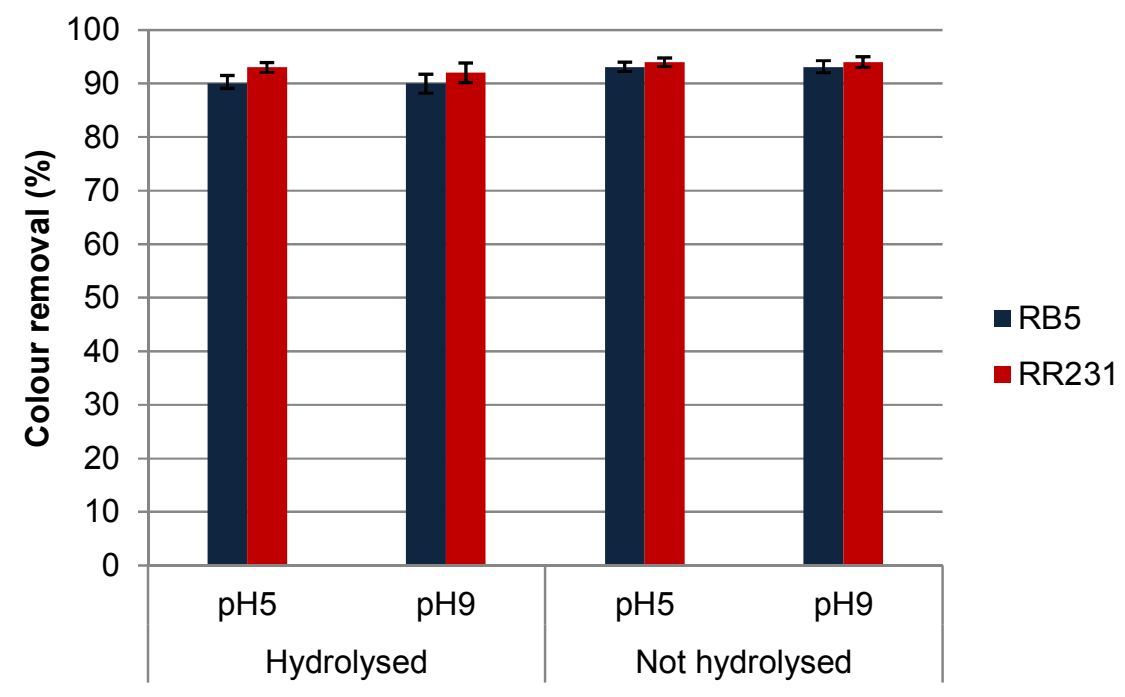

Figure 4. Colour removal by Moringa Oleifera coagulation $(0.1 \mathrm{~g} / \mathrm{L}$ dye, $20 \mathrm{~g} / \mathrm{L} \mathrm{NaCl}$; Moringa oleifera 1,000 mg/L).

As can be seen in Figure 4, Moringa oleifera waste had high coagulation action (90-94\% of colour removal) for all experimental conditions, independently of the $\mathrm{pH}$ or the dye hydrolysis. Previous studies reported the interaction between the sulfonic groups of the dyes and the positive charged proteins of Moringa oleifera $[29,33]$. This interaction is independent of the $\mathrm{pH}$. Moringa oleifera provided good colour removal yield for RR231 whether or not the dye was hydrolised. However, for RB5 the efficiency was slightly lower when the dye was hydrolised. This fact could be attributed to the loss of two sulfonic groups due to the hydrolysis of vinyl sulfonic dyes.

As can be seen in Figure-4, Moringa oleifera waste had high coagulating action whether or not the dye is hydrolysed for both dyes. The dye molecule size or reactive group do not show any influence on the treatment yield (RB5: smaller molecule and two vinyl sulfone reactive groups; RR231: larger molecule and two monochlorotriazine reactive groups). In this sense, the loss of two sulfonic groups due to the hydrolysis of vinyl sulfonic dyes did not affect the efficiency of the Moringa oleifera treatment. Moreover, colour removal yield higher than $90 \%$ was achieved for both dyes, independently of the $\mathrm{pH}$. 
267 In order to optimise the addition of coagulant to the dye solutions, 268 decolourisation tests were performed with solutions of hydrolysed dye at $\mathrm{pH} 9$ to 269 simulate the industrial reactive dye baths. Several Moringa oleifera suspensions 270 were prepared in a range $250 \mathrm{mg} / \mathrm{L}-1250 \mathrm{mg} / \mathrm{L}$. Dye removal results are 271 shown in Figure 5.

272

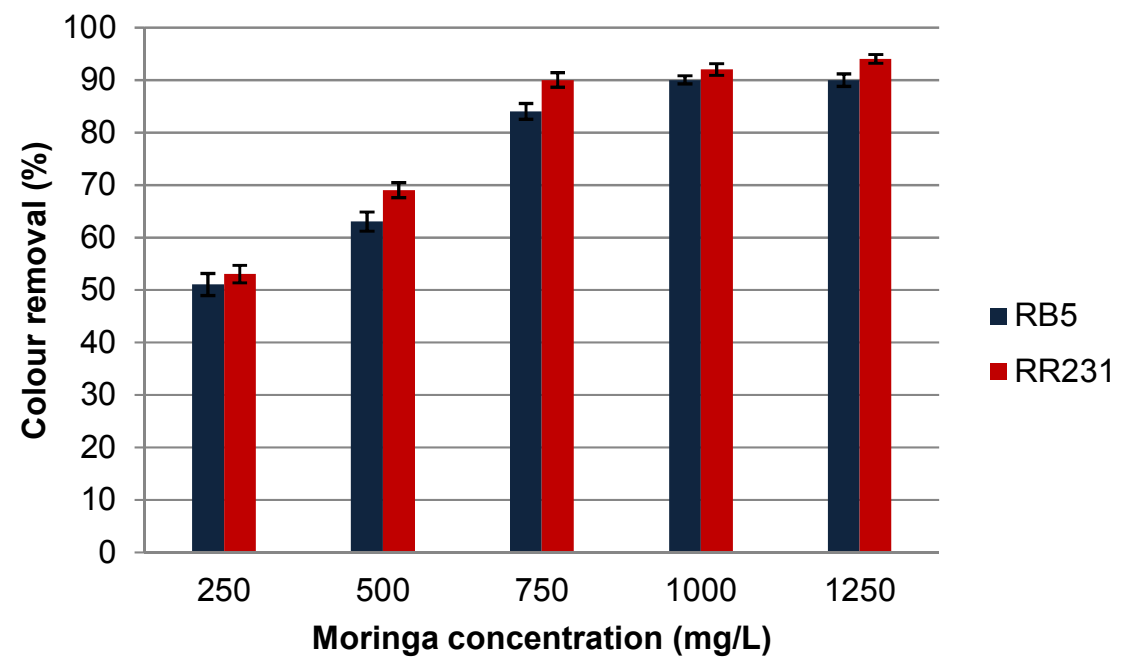

Figure 5 evidences slightly better performance of Moringa oleifera suspensions to remove RR231 than RB5. RR231 removal reached $90 \%$ with the $750 \mathrm{mg} / \mathrm{L}$ Moringa solution whereas RB5 required the addition of $1,000 \mathrm{mg} / \mathrm{L}$ Moringa oleifera to achieve the same level of colour removal. The higher efficiency on the removal of RR231 respect to RB5 could be attributed to its higher number of negative sulfonic groups (8 groups for RR231 respect to 4 groups for RB5.

Figure 5. Coagulation dose optimisation for Moringa oleifera waste suspensions (0.1 g/L hydrolysed dye, $\mathrm{pH} 9,20 \mathrm{~g} / \mathrm{L} \mathrm{NaCl})$.

\subsection{Enzymatic treatment}

285 Results of colour removal obtained by applying enzymatic treatment are shown 286 in Figure 6. In any case, Laccase provided good colour removal yield for RR231 287 dye (88-93\%). For RB5 the efficiency was highly dependent on dye hydrolysis 288 (53-61 \% vs. $88-91 \%)$. This can probably be attributed to the effect of 
289 vinylsulfone reactive groups on the enzyme activity. Zille et al. [35] stated that 290 Laccase reacts with dyes by electrostatic interaction between negative charged 291 sulfonic groups of the dyes and amino acids of the enzymes. The hydrolysis of 292 the two vinilsulfone groups of RB5 implied the loss of two sulfonic groups which 293 did not occur in the case of hydrolysis of the RR231 triazine groups. In fact,

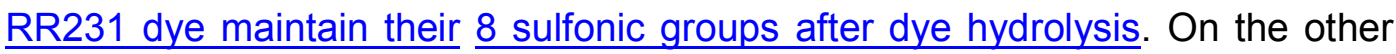
hand, $48 \mathrm{~h}$ reaction time provided slightly better results than $24 \mathrm{~h}$. This results were in accordance with previous studies where an increase of decolourisation was reported when the incubation time was extended from $24 \mathrm{~h}$ to $48 \mathrm{~h}[36]$.

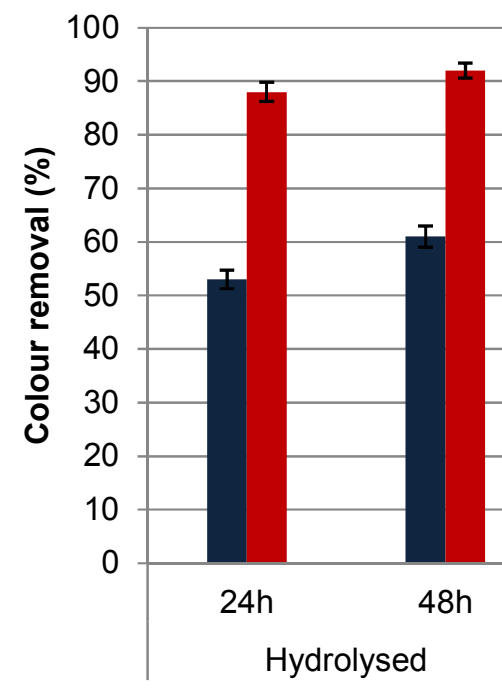

Figure 6. Dye removal by enzymatic treatment $(0.1 \mathrm{~g} / \mathrm{L}$ dye, $20 \mathrm{~g} / \mathrm{L}$ $\mathrm{NaCl}, \mathrm{pH}$ fixed at 5 , enzyme concentration $4 \mathrm{U} / \mathrm{mL}$ ).

Finally, it is important to underline that inhibitory phenomena were not observed in the enzymatic treatments although all the experiments were carried out in high saline medium. Furthermore, the addition of electron transfer mediator or co-substrate was not necessary; unlike other enzymes reported for decolourisation studies [20][19].

\subsection{Comparison of the treatment methods}


310 The three technologies studied in this work demonstrated to be effective for the 311 removal of reactive dyes in simulated residual dyebaths. As can be seen in 312 Table 1, despite the very different chemical constitution (molecular size and 313 reactive groups) of the two selected dyes, for each type of treatment it was 314 possible to find experimental conditions which enabled to remove at least $90 \%$ 315 dye.

Table 1. Colour removal yield (\%) of the different treatments.

\begin{tabular}{|c|c|c|c|c|c|c|c|c|c|c|}
\hline \multirow[b]{3}{*}{ Dye } & \multicolumn{4}{|c|}{ Electrochemical } & \multicolumn{4}{|c|}{ Moringa Oleifera } & \multicolumn{2}{|c|}{ Enzymatic } \\
\hline & \multicolumn{2}{|c|}{ Hydrolysed } & \multicolumn{2}{|c|}{$\begin{array}{c}\text { Not } \\
\text { hydrolysed }\end{array}$} & \multicolumn{2}{|c|}{ Hydrolysed } & \multicolumn{2}{|c|}{$\begin{array}{c}\text { Not } \\
\text { hydrolysed }\end{array}$} & \multirow{2}{*}{$\frac{\text { Hydrolysed }}{\mathrm{pH} 5}$} & \multirow{2}{*}{$\begin{array}{c}\begin{array}{c}\text { Not } \\
\text { hydrolysed }\end{array} \\
\mathrm{pH} 5 \\
\end{array}$} \\
\hline & $\mathrm{pH} 5$ & $\mathrm{pH} 9$ & $\mathrm{pH} 5$ & $\mathrm{pH} 9$ & $\mathrm{pH} 5$ & $\mathrm{pH} 9$ & $\mathrm{pH} 5$ & $\mathrm{pH} 9$ & & \\
\hline RB5 & 95 & 96 & 96 & 96 & 90 & 90 & 93 & 94 & 61 & 90 \\
\hline RR231 & 98 & 100 & 99 & 100 & 93 & 92 & 93 & 94 & 92 & 93 \\
\hline
\end{tabular}

318

319

The electrochemical treatment provided excellent results: colour removal in the range $95-100 \%$, almost independent on dye hydrolysis and $\mathrm{pH}$. The characteristic high salinity of the industrial reactive dye effluents is a factor that enhances the performance of the electrochemical treatment and reduces the electrical consumption and consequently, the cost of the treatment. An additional advantage of the electrochemical method is that it can be considered as a clean technology because the addition of chemical reagents is not required, no wastes are generated and dyes are degraded, which enables the reuse of the treated effluent.

The Moringa Oleifera waste applied to the coagulation of reactive dyes has also shown to be an interesting option. Both dyes exhibited removal yield results in the range $90-94 \%$. As in the previous case, the salinity of the effluent also demonstrated to be a positive factor for the treatment efficiency (see section 3.2). In addition, results are also almost independent of the other variables: $\mathrm{pH}$ and dye hydrolysis. For these reasons, to the use of Moringa Oleifera waste as reactive dye coagulant constitutes an interesting low-cost and natural alternative to substitute the conventional chemical coagulants-flocculants. On another hand, the addition of Moringa oleifera supposes a low increase of COD which can be easily eliminated in the subsequent biological treatment plant. The increase of COD is slight in comparison with the organic content of industrial textile waste waters. In this sense, the use of Moringa oleifera as well as the 
340 other two methods described in this work are thought as specific methods to remove non biodegradable dyes and they are proposed as a previous step to biological aerobic treatment. Once the dye is eliminated the water can be discharged to the biological plant to follow up with the degradation of the rest of organic matter.

With respect to enzymatic treatment, results can be considered in general very positive because Laccase activity is not influenced by the salinity of the effluent, as it was shown in section 3.3, in opposite to previous studies which reported inhibitory effects caused by the high salinity of the dye effluents [40]. .However, the treatment is very sensitive to $\mathrm{pH}$ variations: the effluent should be buffered at $\mathrm{pH}$ 5. This implies an additional cost and an increase of wastewater salinity as reactive dye effluents which are typically alkaline. In addition, the dye hydrolysis constitutes also an important factor to take into account in the case of vinylsulfonic dyes.

\section{CONCLUSIONS}

356 The comparison of the three decolourisation methods studied in this work leads to the conclusion that the electrochemical treatment was the most efficient (95$100 \%$ colour removal yield).

The coagulation with Moringa oleifera also achieved high colour removal 360 efficiency for both dyes (91-94\%).

361 Enzymatic treatment provided good colour removal yield for RR231 (92-93\%) 362 whereas for RB5 the efficiency was highly dependent on dye hydrolysis (61363 90\%). That is to say, in the case of the vinylsulfone dye, this treatment showed a marked dependence on dye hydrolysis, being moderately efficient for the hydrolysed dye and highly efficient without hydrolysis. This difference can probably be attributed to the effect of sulfonic groups on the enzyme activity when the vinylsulfone dye is not hydrolysed.

On the other hand, results of-Eelectrochemical and Moringa oleifera treatments were almost independent on $\mathrm{pH}$ whereas in the case of the enzymatic treatment, the $\mathrm{pH}$ should be carefully controlled ( $\mathrm{pH}$ buffered at 5). 
371 In addition, both electrochemical and Moringa oleifera treatments promising to remove colour of industrial effluents containing reactive dyes, because they were very efficient independently on $\mathrm{pH}$ range and dye hydrolysis conditions and because their yield is enhanced by the effluent salinity.

$\underline{\text { Therefore, both electrochemical and Moringa Oleifera treatments have shown to }}$ be attractive as new alternative methods for colour removal, whereas Laccase can only be applied for the removal of reactive dyes under controlled conditions.

\section{ACKNOWLEDGEMENTS}

The authors thanks the Spanish Ministry of Economy (MINECO) for its financial support (Project CTM2012-31461).

\section{REFERENCES}

1. M. Solis, A. Solis, H.I. Perez, N. Manjarrez and M. Flores, Microbial decolouration of azo dyes: A review, Process Biochemistry, 47 (2012) 17231748.

2. IARC. Overall evaluations of carcinogenicity to humans. In: IARC monographs, International Agency for Research on Cancer, Lyon 2004, pp. 182.

3. V. López-Grimau, M. Riera-Torres, M. Lopez-Mesas and C. GutierrezBouzan, Removal of aromatic amines and decolourisation of azo dye baths by electrochemical treatment, Color. Technol., 129 (2013) 267-273.

4. P.A. Carneiro, M.E. Osugi, C.S. Fugivara, N. Boralle, M. Furlan and M.V. Zanoni, Evaluation of different electrochemical methods on the oxidation and degradation of Reactive Blue 4 in aqueous solution, Chemosphere, 59 (2005) 431-439.

5. V. López-Grimau and C. Gutiérrez-Bouzán, Selection of decolorization methods of reactive dye baths for reuse purposes. In Dyeing: Processes, techniques and applications. Jie Fu; Nova Publishers Inc., New York 2013, Chapter 10, pp. 205-216. 
401 6. A. Pala and E. Tokat, Color removal from cotton textile wastewater in an

402 activated sludge system with various additives. Water Res., 38 (2002) 2920-

$403 \underline{2925 .}$

404

76. A. Gurses, Ç. Dogar, S. Karaca, M. Açikyidiz and R. Bayrak, Production of

405 granular activated carbon from waste Rosa canina sp. Seeds and its adsorption

406 characteristics for dye, J. Hazard. Mater., 131 (2006) 254-259.

407 87. S. Wang and Z.H. Zhu, Effects of acidic treatment of activated carbons on 408 dye adsorption, Dyes Pigm., 75 (2007) 306-314.

409 98. J.J. Qin, M.H. Oo and K.A. Kekre,. Nanofiltration for recovering wastewater 410 from a specific dyeing facility. Sep. Purif. Technol, 56, (2007) 199-203.

411 109. I. Petrinic, N.P. Andersen, S. Sostar-Turk and A.M. Le Marechal, The 412 removal of reactive dye printing compounds using nanofiltration, Dyes Pigm., 74 413 (2007) 512-518.

414 1110. V. Golob, A. Vinder and M. Simonic, Efficiency of the 415 coagulation/flocculation method for the treatment of dyebath effluents, Dyes 416 Pigm., 67 (2005) 93-97.

417 1211. A.Y. Zahrim, C. Tizaoui and N. Hilal. Evaluation of several commercial 418 synthetic polymers as flocculant aids for removal of highly concentrated C.I. 419 Acid Black 210 dye. J Hazard Mater., 182 (2010) 624-630.

420 1312. M. Constapel, M. Schellenträger, J. M. Marzinkowski and S. Gäb, 421 Degradation of reactive dyes in wastewater from textile industry by ozone: 422 analysis of the products by accurate masses, Water Res. 43 (2009) 733-743.

423 1413. S. Song, H. Ying, Z. He and J.Chen, Mechanism of decolourization and 424 degradation of $\mathrm{Cl}$ Direct Red 23 by ozonation combined with sonolysis, 425 Chemosphere, 66 (2007) 1782-1788.

426 1514. V.K. Gupta, Suhas, Application of low-cost adsorbents for dye removal 427 A review. J. Environ. Manage. 90 (2009) 2313-2342.

428 1615. E.A. Oliveira, S.F. Montanher and M.C. Rollemberg, Removal of textile 429 dyes by sorption on low-cost sorbents. A case study: sorption of reactive dyes 430 onto Luffa cylindrica, Desal. Wat. Treat., 25 (2011) 54-64. 
431 1716. Y. Chun-Yang, Emerging usage of plant-based coagulants for water and 432 wastewater treatment. Process Biochem., 45 (2010) 1437-1444.

433 1817. A.K. Verma, R.D. Dash and P. Bhunia, A review on chemical 434 coagulation/flocculation technologies for removal of colour from textile 435 wastewaters. J. Environ. Manage., 93 (2012) 154-168

436 1918. P.D. Shah, S.R. Dave and M.S. Rao, Enzymatic degradation of textile 437 dye Reactive Orange 13 by newly isolated bacterial strain Alcaligenes faecalis 438 PMS-1. Int. Biodeterior. Biodegrad., 69 (2012) 41-50.

439 2019. L. Mendoza, M. Jonstrup, R. Hatti-Kaul and B. Mattiasson, Azo dye 440 decolorization by laccase/mediator system in a membrane reactor: Enzyme and 441 mediator reusability. Enzyme Microb. Technol. 49 (2011) 478-484.

442 2120. F.P. Van der Zee and S. Villaverde. Combined anaerobic-aerobic 443 treatment of azo dyes-A short review of bioreactor studies. Water Res., 39 444 (2005) 1425-1440.

445 2221. S.Papic, D. Vujevic, N. Koprivanac and D.Sinko, Decolourization and 446 mineralization of commercial reactive dyes by using homogeneous and 447 heterogeneous Fenton and UV/Fenton processes. J. Hazard. Mater., 164 448 (2009) 1137-1145.

449 2322. Y. Li, T. Zhou, X. Lu, J. Wang and F-S. Wong, Rapid decolorization and 450 mineralization of simulated textile wastewater in a heterogeneous Fenton like 451 system with/without external energy. J. Hazard. Mater. 165 (2009) 193-199.

452 2423. M. Muruganandham and M. Swaminathan, Photocatalytic decolourisation 453 and degradation of Reative Orange 4 by $\mathrm{TiO}_{2}$-UV process. Dyes Pigm.. 68 454 (2006) 133-142.

455 2524. T. Visa, M. Sanchez, V. López-Grimau, R. Navarro and S. Reche, 456 Gutiérrez-Bouzán, M.C. Photocatalysis with titanium dioxide to remove colour of 457 exhausted reactive dyebaths without $\mathrm{pH}$ modification. Desal. Water Treat.. 45 $458 \quad$ (2012) 91-99.

459 2625. M.S. Morsi, A.A. Al-Sarawy and W.A. Shehab El-Dein, Electrochemical 460 degradation of some organic dyes by electrochemical oxidation on a $\mathrm{Pb} / \mathrm{PbO}_{2}$ 461 electrode. Desal. Wat. Treat. 26 (2011) 301-308. 
462 2726. V. Lopez-Grimau and M.C. Gutierrez, Decolourisation of simulated 463 reactive dyebath effluents by electrochemical oxidation assisted by UV light. 464 Chemosphere. 62 (2006) 106-112.

465 2827. A. Ndabigengesere and K.S. Narasiah, Quality of water treated by 466 coagulation using Moringa oleifera seeds. Water. Res.. 32 (1998) 781-791.

467 2928. J. Beltran-Heredia and J. Sanchez-Martin, Azo dye removal by Moringa 468 oleífera seed extract coagulant. Color. Technol.. 124 (2008) 310-317.

469 3029. P.D. Shah, S.R. Dave and M.S. Rao, Enzymatic degradation of textile 470 dye Reactive Orange 13 by newly isolated bacterial strain Alcaligenes faecalis 471 PMS-1. Int. Biodeterior. Biodegrad.,69 (2012) 41-50.

472 3130. A. Kunamneni, I. Ghazi, S. Camarero, A. Ballesteros, F.J. Plou and M. 473 Alcalde, Decolorization of synthetic dyes by laccase immobilized on epoxy474 activated carriers. Process Biochem., 43 (2008) 169-178.

475 32. S. Rodríguez Couto, M.A. Sanromán and G.M. Gübitz, Influence of redox 476 mediators and metal ions on synthetic acid dye decolourization by crude laccase from Trametes hirsute. Chemosphere, 58 (2005) 417-422. 33. M. Vilaseca, V. López-Grimau and C. Gutiérrez-Bouzán. Valorization of Waste Obtained from Oil Extraction in Moringa Oleifera Seeds: Coagulation of Reactive Dyes in Textile Effluents. Materials 7 (2014), 6569-6584.

34. APHA-AWWA-WEF. Method 2540 (F). Settleable solids. Standard Methods for the Examination of Water and Wastewater. 20th ed. Washington, D.C.: American Public Health Association; 1998.

35. A. Zille, T. Tzankov, G. Gübitz and A. Cavaco-Paulo, Immobilized laccase for decolourization of Reactive Black 5 dyeing effluent. Biotechnol. Lett., 25 486 (2003) 1473-1477. 36. K. Murugesan, A. Dhamija, I.H. Nam, Y.M. Kim and Y.S. Chang. Decolourization of reactive black 5 by laccase: Optimization by response surface methodology. Dyes Pigm. 75 (2007) 176-184. 37. M. Riera-Torres and C. Gutiérrez-Bouzán. Optimisation of the 491 electrochemical and UV combined treatment to remove colour and organic 
1

2

3

4

5

6

7

8

9

10

11

12

13

14

15

16

17

492 halogenated compounds of textile effluents. Sep. Purif. Technol. 98 (2012),

493 375-382.

494 38. M. Sala, A.I. del Río, J. Molina, F. Cases and M.C. Gutiérrez-Bouzán.

495 Influence of Cell Design and Electrode Materials on the Decolouration of Dyeing

496 Effluents. Int. J. Electrochem. Sci. 7 (2012) 12470 - 12488.

497 39. A.K. Verma, R.D. Dash and P. Bhunia. A review on chemical

498 coagulation/flocculation technologies for removal of colour from textile

499 wastewaters. J. Environ. Manage. 93 (2012), 154-168.

500 40. E. Rosales, M. Pazos and M.A. Sanromán. Comparative efficiencies of the

501 decolourisation of leather dyes by enzymatic and electrochemical treatments.

502 Desalination 278 (2011) 312-317. 